\title{
Seismic Reflection and Refraction Investigations in Potrero Canyon, Los Angeles County, California
}

M. N. Jaasma, R. D. Catchings, M. R. Goldman, M. J. Rymer and W. H. K. Lee U. S. Geological Survey

345 Middlefield Rd. MS 977

Menlo Park, CA 94025

1997

Open-File Report 97-283

This report is preliminary and has not been reviewed for conformity with U.S. Geological Survey editorial standards or with the North American Stratigraphic Code. Any use of trade, firm, or product names is for descriptive purposes only and does not imply endorsement by the U.S. Government. 


\section{CONTENTS}

INTRODUCTION

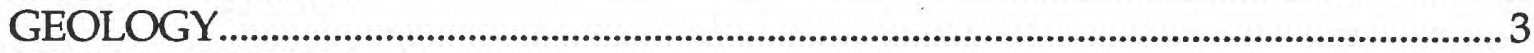

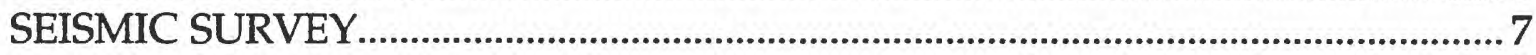

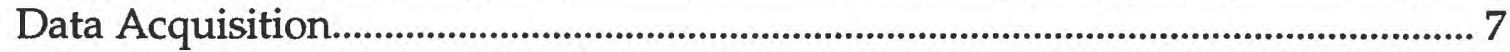

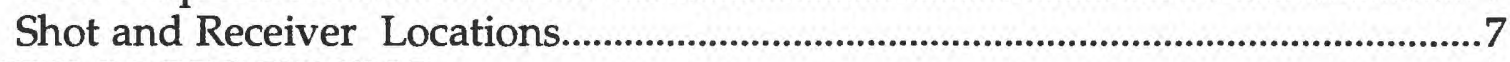

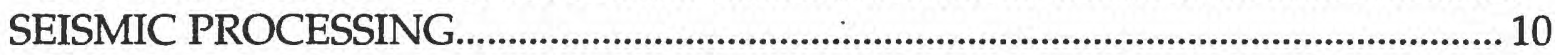

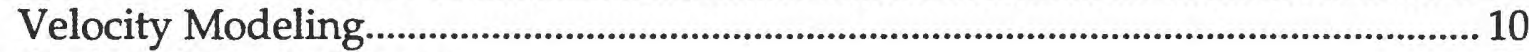

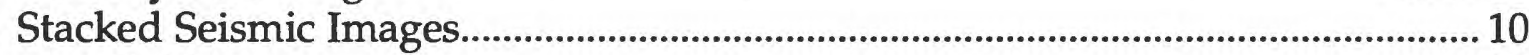

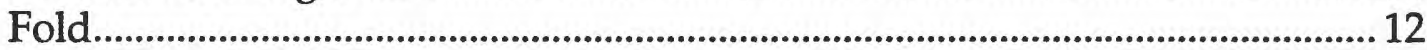

INFERRED STRONG SHAKING IN POTRERO CANYON …................................ 12

Potential Earthquake-Hazards.......................................................................... 15

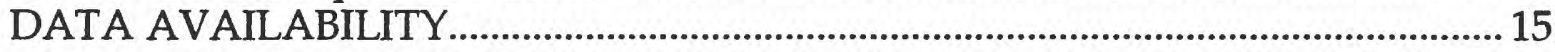

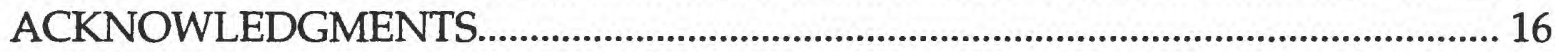

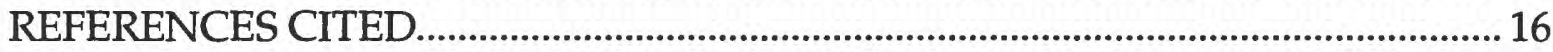

APPENDIX A

TABLES

1. Acquisition parameters for Potrero Canyon ..................................................

FIGURES

1. Index map of the San Fernando Valley and Santa Susana

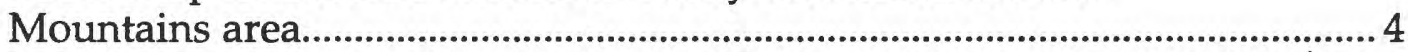

2. Map of Potrero Canyon with the location of seismic profile relative to surface cracks.......................................................................................... 5

3. Geologic map of the western end of Potrero Canyon....................................... 6

4. Relative geophone elevations as a function of distance along the

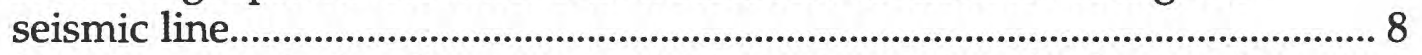

5. Geophone variation from a straight line connecting the first and last geophone along the seismic line.................................................................... 8

6. Relative shot point elevations as a function of distance along the seismic line.

7. Shot point variation from a straight line connecting the first and last shot point along the seismic line.

8. Seismic P-wave velocity model derived from inversion of first arrivals.

9. Uninterpreted (a) and interpreted (b) migrated seismic reflection image for the upper $100 \mathrm{~m}$ beneath the seismic array..

10. Uninterpreted (a) and interpreted (b) migrated seismic reflection image of the shallow crust $(<1.5 \mathrm{~km})$ beneath Potrero Canyon, CA......... 14

11. Fold as a function of common depth points along the seismic line. 15 


\section{INTRODUCTION}

Potrero Canyon, California, is one of four areas where ground cracks were observed (Hart et al. 1995, Hecker et al., 1995, Rymer et al., 1995, Treiman et al., 1995) following the 17 January, 1994 Northridge earthquake (Fig. 1).

The main shock of the Northridge earthquake was generated by a southdipping blind thrust fault (USGS and SCEC, 1994), located approximately $22 \mathrm{~km}$ south-southeast of Potrero Canyon. Observations of surface cracks (Fig. 2) at Potrero Canyon are important, because 1) the cracks are located at the approximate surface projection of the blind thrust fault and 2) Potrero Canyon and other parts of the Santa Susana Mountains are currently undergoing rapid suburban growth. If the surface cracks are tectonically related to the Northridge earthquake, the earthquake hazard of the area may be significant.

In February, 1994, the U.S. Geological Survey (USGS) acquired a seismic reflection/refraction profile across Potrero Canyon to explore the subsurface for evidence of faults that may be associated with the observed surface cracks. The USGS also conducted a paleoseismological trenching investigation across the surface cracks to look for evidence of faulting (Rymer et al., 1995). For correlation purposes, the seismic line was located within a few meters of one of the trenches (Fig. 2).

This report presents data processing and acquisition parameters for the seismic survey acquired at Potrero Canyon. In addition, this report summarizes some of the findings presented in Catchings et al. (in press).

\section{GEOLOGY}

Potrero Canyon is located within the Transverse Ranges of southern California and is one of several east-west-trending valleys that have undergone late Cenozoic faulting and folding (Wentworth and Yerkes, 1972). The valley floor of Potrero Canyon is about $200 \mathrm{~m}$ wide at the location of the seismic survey, but varies in width along the length of the canyon (Fig. 3). Surface and near-surface sediment types of the valley floor consist of a series of Holocene sand, gravel, and clay loam within the upper few meters (Rymer et al., 1995). The basement and canyon walls consist of sandstone, conglomerate, and mudstone of the Pliocene Pico Formation (Winterer and Durham, 1962). Exposed rocks on the south side of the canyon dip to the north $\left(\sim 50^{\circ}\right.$ to $\left.70^{\circ}\right)$ and those on the north side of the canyon, near the seismic line, dip to the southwest $\left(20^{\circ}\right.$ to $50^{\circ}$ ) (Winterer and Durham, 1962, Rymer et al., 1995, Fig. 3). Surface exposures of bedrock and associated faults and folds in Potrero Canyon indicate that structures vary greatly over relatively short distances, ranging from steeply dipping strata on fold limbs to sub-horizontal layers. 


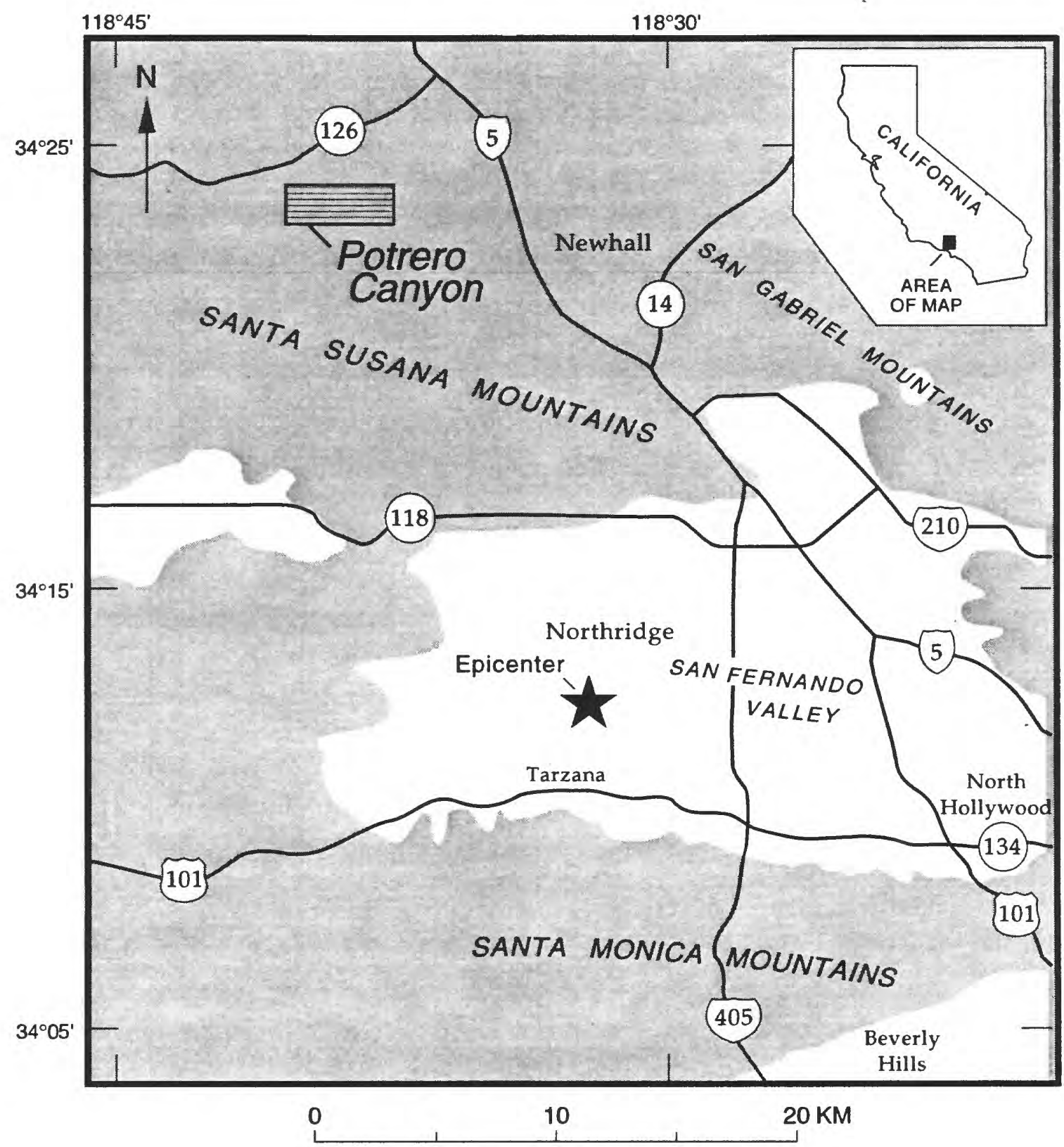

Figure 1. Index map of the San Fernando Valley and Santa Susana Mountains area, Los Angeles County, California, showing epicenter (star) of the 1994 Northridge earthquake and Potrero Canyon (box). 


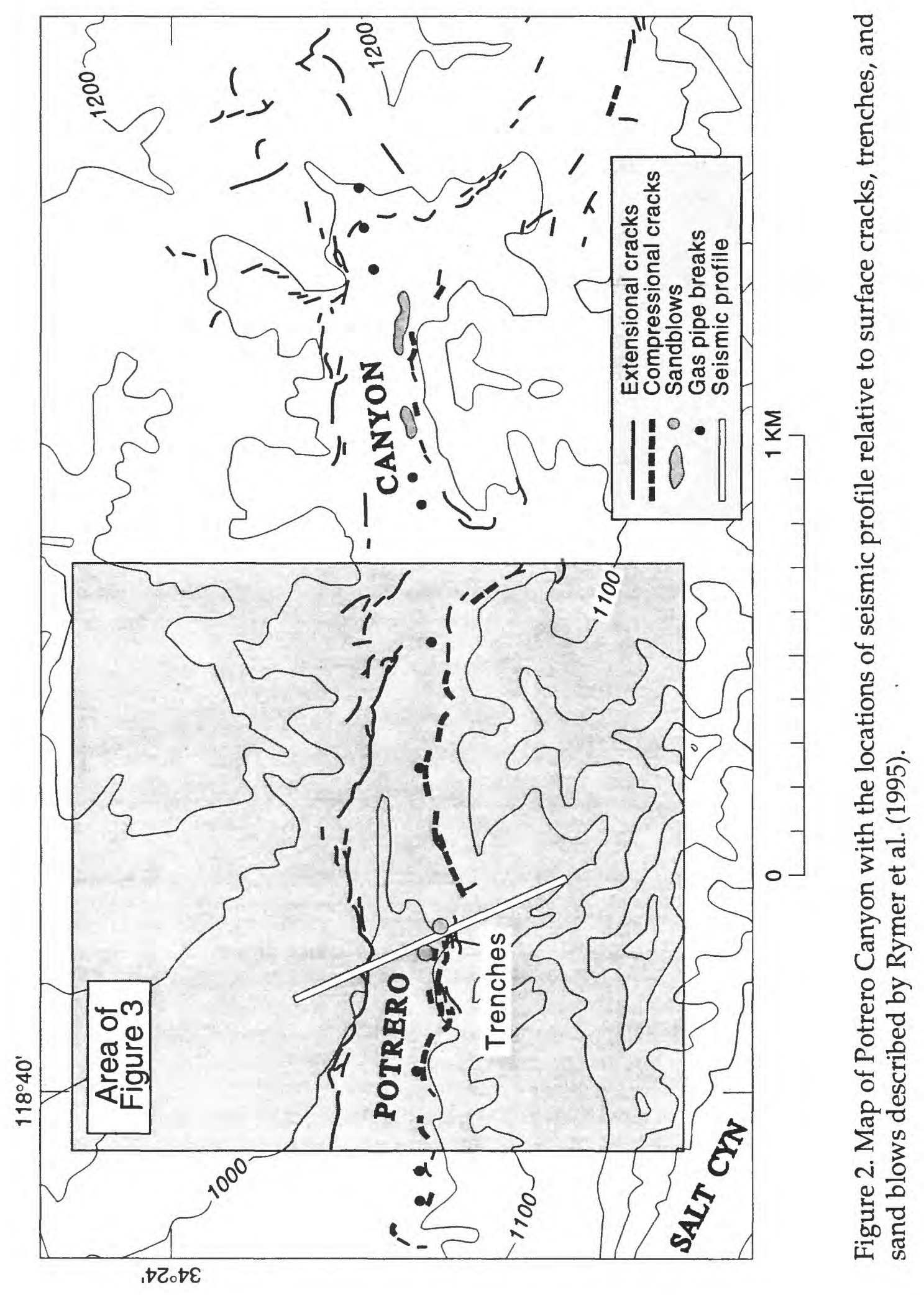




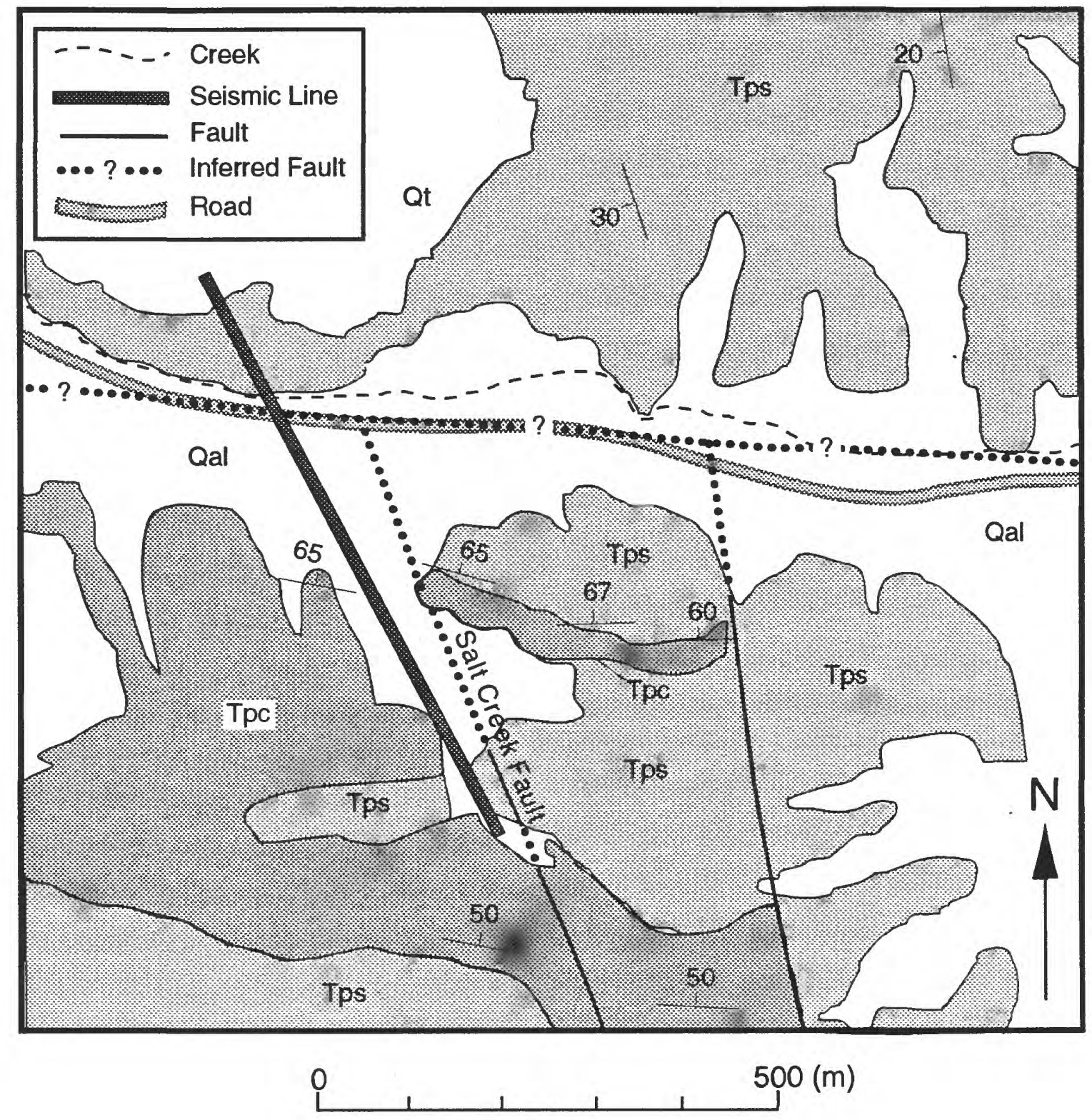

Figure 3. Geologic map of the western end of Potrero Canyon (from Winterer and Durham, 1962). Faults mapped by Winterer and Durham include an inferred fault and two faults extending to the southeast from the canyon axis. The seismic line (bold, black line) subparallels the Salt Creek fault and crosses the inferred fault located near the canyon axis. Strike and dip (numbers in degrees) of strata are shown. Qal, Qt, Tpc, and Tps refer to Quaternary alluvium, Quaternary terrace deposits, and Pliocene Pico Formation, respectively. 


\section{SEISMIC SURVEY}

Data Acquisition

In February, 1994, the USGS acquired high-rsolution seismic reflection and refraction data across Potrero Canyon along a NW-SE-trending, $\sim 700-\mathrm{m}-$ long line (Fig. 3). Seismic sources consisted of 1-lb charges of ammonium nitrate buried to depths of about $2 \mathrm{~m}(6 \mathrm{ft})$ and spaced approximately $15 \mathrm{~m}$ apart (Appendix A). Prior to data acquisition, shot and receiver locations were determined using a measuring tape and compass. After the data were acquired, shot and sensor locations were measured more precisely using an electonic distance meter. The locations are accurate to within $0.001 \mathrm{~m}$.

Sensors consisted of 46 strings of six $8-\mathrm{Hz}$ Mark Products geophones spaced $15 \mathrm{~m}$ apart and connected by cable. The six geophones at each site were grouped into a cluster that was about $0.3 \mathrm{~m}$ in diameter. The seismic data were recorded on a 64-channel recording system using a 2-ms sampling interval without filters. Each shotpoint was co-located at a receiver location and the shot time was determined by the up-hole time. A total of 31 shots were fired along the $\sim 700-\mathrm{m}$-long line (Table 1). For each shot, five-second records were recorded in PC-SUDS format on a PC hard disk. The seismic data were then transferred to optical disk for permanent storage.

Table 1. Acquisition parameters for seismic profile at Potrero Canyon. Distances

\begin{tabular}{|c|c|c|c|c|c|}
\hline Orientation & $\begin{array}{c}\text { Total } \\
\text { Receiver } \\
\text { Length (m) }\end{array}$ & $\begin{array}{l}\text { Length of } \\
\text { Shot Point } \\
\text { Line }(\mathrm{m})\end{array}$ & $\begin{array}{l}\text { No. of } \\
\text { Shots }\end{array}$ & $\begin{array}{l}\text { No. of } \\
\text { CDP's }\end{array}$ & $\begin{array}{l}\text { Maximum } \\
\text { Fold }\end{array}$ \\
\hline NW-SE & 694.38 & 496.19 & 31 & 84 & 31 \\
\hline
\end{tabular}

Shot and Receiver Locations

A plot of geophone elevation variation is shown in Figure 4. The relative elevations along the seismic line vary by about $35 \mathrm{~m}$. Geophone locations varied from a staight line (connecting the endpoints) by not more than $5 \mathrm{~m}$ (Fig. 5, Appendix A).

Shot points were not located along the northeastern $160 \mathrm{~m}$ of the line, because shot holes could not be drilled on the steep slopes. Figure 6 shows shot point elevation as a function of distance along the seismic line. Because shot points were located prior to making electronic measurements, the line of shot points also varied from a straight line. There was about a $4.3-\mathrm{m}$ variance from a straight line along the $\sim 500$-m-long array of shots (Fig. 7, Appendix A). 




Figure 4. Relative geophone elevations as a function of distance along the seismic line. Elevation is relative to the topographically lowest geophone along the line. Distance is relative to the first geophone at the southeastern end of the line.

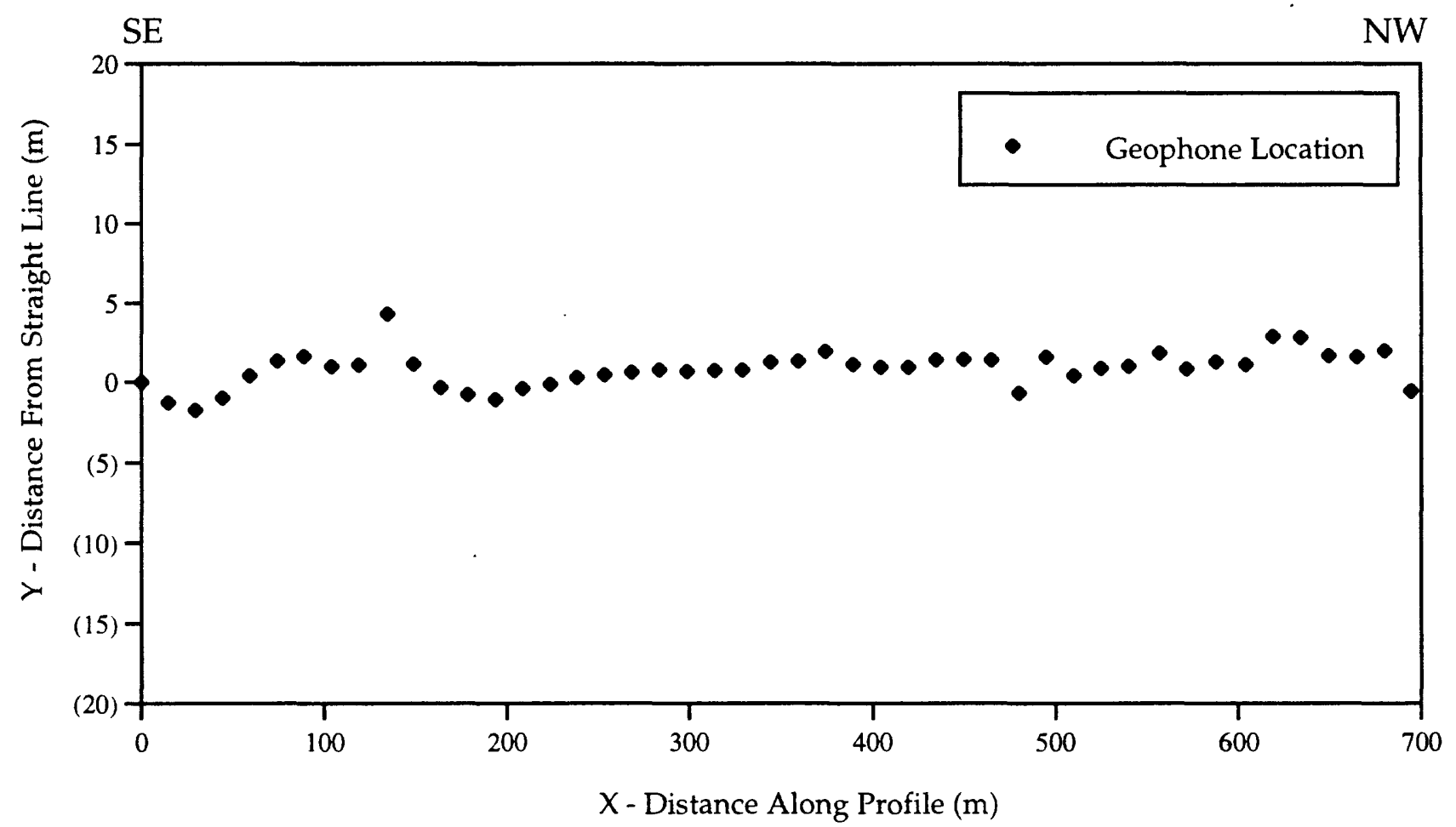

Figure 5. Geophone variation from a straight line connecting the first and last geophone. 


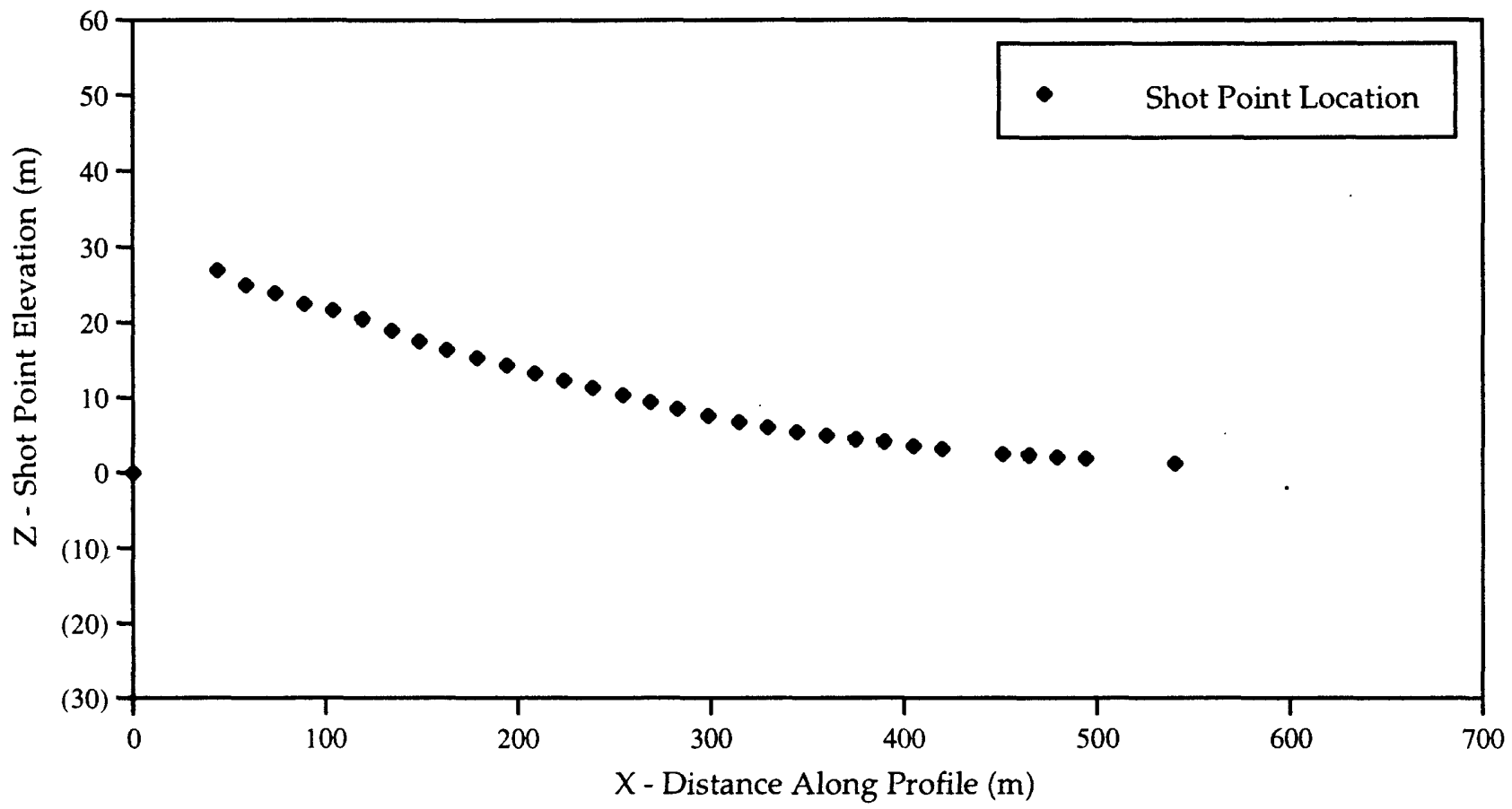

Figure 6. Relative shot point elevations as a function of distance along the seismic line. Elevation is relative to the topographically lowest geophone along the line. Distance is relative to the first geophone at the southeastern end of the line.



Figure 7. Shot point variation from a straight line connecting the first and last shot point. 


\section{SEISMIC PROCESSING}

The data were processed using both seismic refraction and seismic reflection techniques. Using these two approaches on the same data set increases our understanding of the subsurface by providing independant constraints and interpretations.

Velocity Modeling

In seismic refraction processing, the first-arrivals and intercept times were measured and a preliminary model was developed based on calculated velocities. This model was then input into a velocity inversion routine developed by Hole (1992). The final velocity model is shown in Figure 8 (from Catchings et al. (in press)).

In general, velocities range from less than $300 \mathrm{~m} / \mathrm{s}$ at the surface to about $5000 \mathrm{~m} / \mathrm{s}$ at $100 \mathrm{~m}$ depth. At the surface, there are two areas (near meter 375 and meter 550$)$ with unusually low velocities $(<300 \mathrm{~m} / \mathrm{s})$ and a higher gradient. At these locations, velocities increase from less than $300 \mathrm{~m} / \mathrm{s}$ to more than $3000 \mathrm{~m} / \mathrm{s}$ within the upper $50 \mathrm{~m}$. The low-velocity $(<300 \mathrm{~m} / \mathrm{s})$ areas are interpreted to result from lesser consolidated sediments, such as open fractures generated by earthquake-induced shaking. Although we cannot determine whether or not the low-velocity areas existed prior to the development of fractures, the areas of low velocities correspond to the surface locations where earthquake-generated surface cracks were mapped (Fig. 2, Rymer et al., 1995). Although the entire profile had redundant ray coverage ranging from approximately three separate ray paths to more than 75 separate ray paths, the southeasternmost $30 \mathrm{~m}$ and the northwesternmost $160 \mathrm{~m}$ of the line were not reversed (Figure 8). Thus, the model is best resolved near the central part of the model.

Stacked Seismic Images

Velocities inferred from stacking data were derived from the velocity model discussed above. The following steps were involved in data processing:

i Geometry installation

ii Trace editing

iii Bandpass filtering

iv Timing corrections

$\begin{array}{llll}\text { v } & \text { Velocity analysis } & \text { ix } & \text { Muting } \\ \text { vi } & \text { Moveout correction } & \text { x } & \text { F-K filtering } \\ \text { vii Velocity inversion } & \text { xi } & \text { Stacking } \\ \text { viii Elevation statics } & \text { xii } & \text { Migration }\end{array}$

The locations determined from the electronic-distance-meter surveys were imported directly into our Promax processing routine. Due to poor coupling between the geophones and the earth, malfunctioning geophones, and/or local noise sources along the seismic line, some unusually noisy traces had to be 


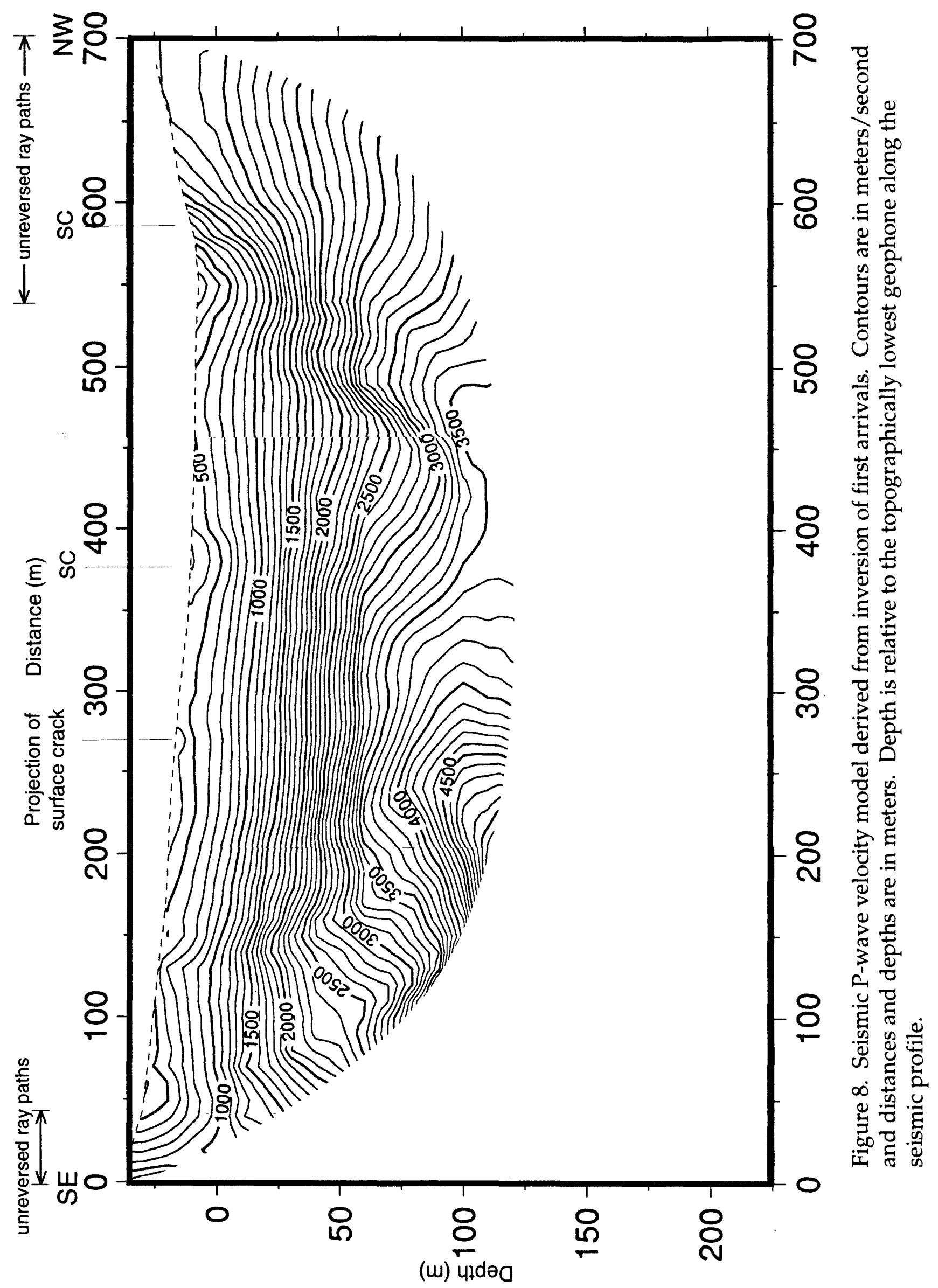


removed. The affected traces often varied from shot to shot; thus, separate trace edits were employed for each shot gather. We used bandpass filtering with a low cut of $30 \mathrm{~Hz}$ to remove most surface waves, shear waves, and cultural noise. A high cut of about $250 \mathrm{~Hz}$ was used to remove wind noises and other highfrequency noises.

Stacked migrated seismic images for the uppermost $100 \mathrm{~m}$ and $1500 \mathrm{~m}$ sections of the subsurface are shown in Figure 9 and Figure 10, respectively. Along the horizontal axis, the locations of the observed surface cracks (Fig. 2) are indicated by the letters "SC". The smaller numbers at the top of the figure refer to distance in meters, comparable with locations in the velocity model. The larger numbers refer to common depth points (CDP), whereby each CDP is about $7.5 \mathrm{~m}$. The elevation of the topographically highest geophone is used as a datum.

The seismic reflection data in the stacked images shown in Figure 9 indicate variations in structure that are consistent with the velocity data. A poor image of the upper $100 \mathrm{~m}$ along the southeastern end of the profile is attributed to the high dips $\left(65^{\circ}-70^{\circ}\right)$ of the near-surface strata along that segment of the line. From about $600 \mathrm{~m}$ to $1000 \mathrm{~m}$ depth, a series of reverse-faulted reflectors dip to the southeast (Fig. 10), and there are indications of shallow faulting in the upper 100 $\mathrm{m}$.

\section{Fold}

Fold for the Potrero Canyon survey varied systematically from five at the southeastern end to a maximum fold of 31 near the center of the line (Fig. 11). From the center of the line to the northwestern end, fold decreased from a high of 31 to one. The fold pattern resulted from our use of a "shoot through" acquisition method, whereby the receiver array remained fixed as shots were fired into the array.

\section{INFERRED STRONG SHAKING IN POTRERO CANYON}

The relative distance of Potrero Canyon from the earthquake's epicenter and the rarity of other locations where surface cracks developed following the main shock, indicate that shaking in the Potrero Canyon was unusually strong. Strong motion accelerometers placed in Potrero Canyon following the Northridge earthquake, also indicate that Potrero Canyon experienced unusually strong shaking from aftershocks. Thick accumulations of sediments are known to generate strong local shaking, but the seismic data indicate that unconsolidated sediments are no more than $20 \mathrm{~m}$ thick along the seismic line. We infer shallow faulting at imaged low velocity zones near mapped surface cracks. We also infer that recorded strong ground shaking may have resulted from co-seismic movement on existing faults beneath Potrero Canyon or that seismic energy was channelled along the faults beneath Potrero Canyon. 


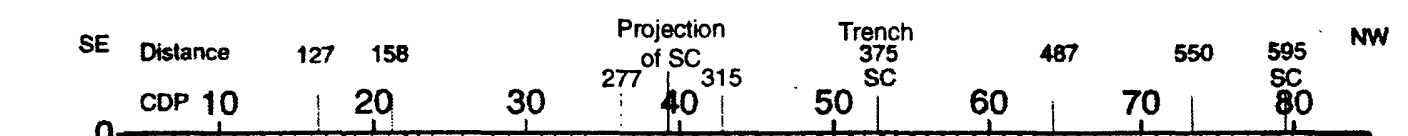
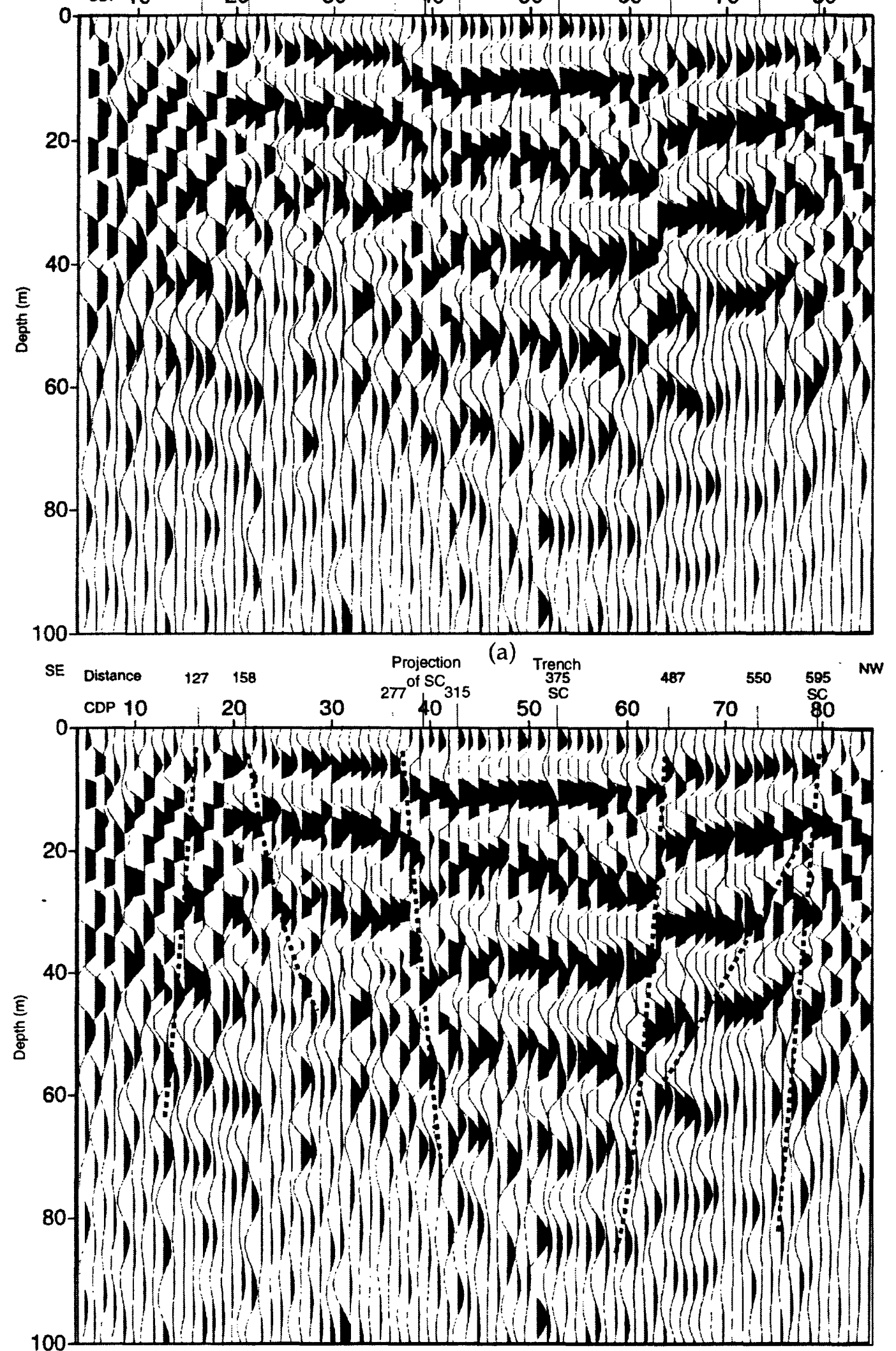

(b)

Figure 9. Uninterpreted (a) and interpreted (b) migrated seismic reflection image of the upper $100 \mathrm{~m}$ beneath the seismic array. The horizontal axis is Common Depth Point (CDP) number. The vertical axis is depth in meters and is relative to the topographically highest geophone along the surface of the seismic line. The location of the surface cracks (SC) and the distance scale of the velocity model of Figure 8 are shown along the top. 


\section{Projection of Trench surface crack SC}

\section{SE} 20 40 60 80

0

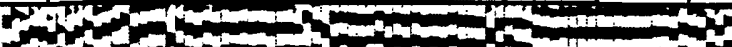

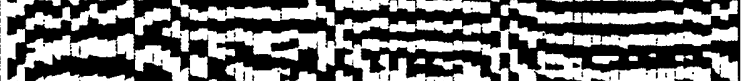

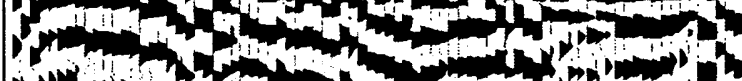

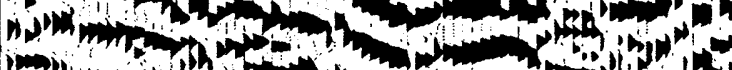

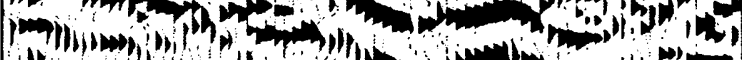

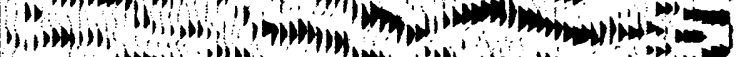
Bnilln' 'on:

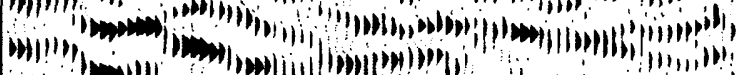

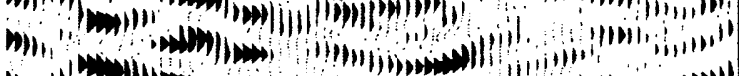

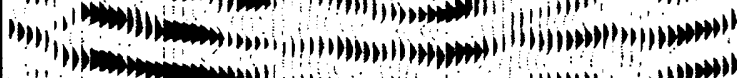

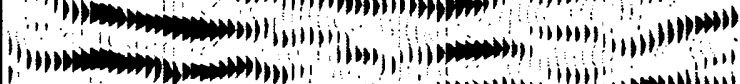

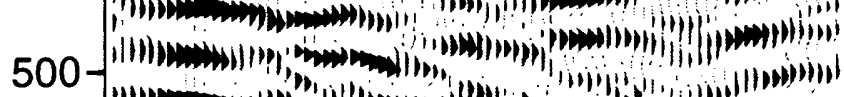

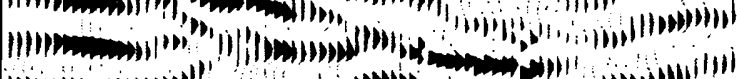

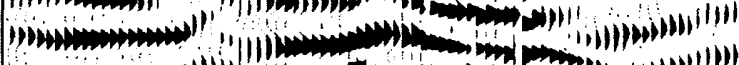

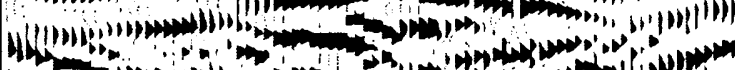

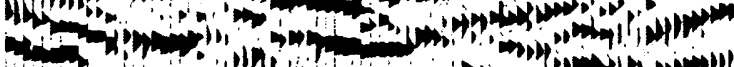



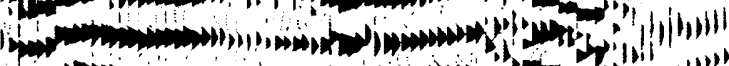
opd mom m.

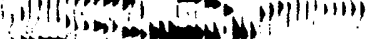

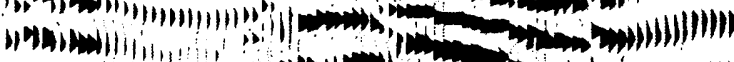

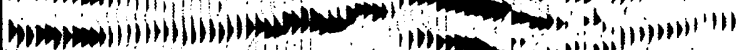

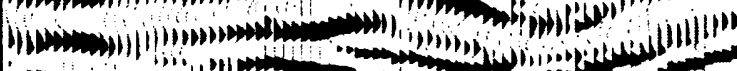
$1000-\left(\frac{1}{10}\right.$

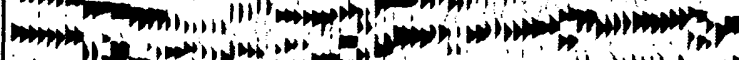

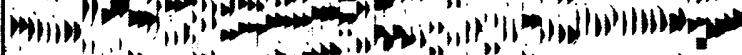

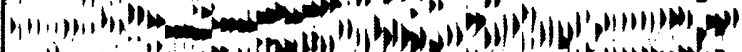

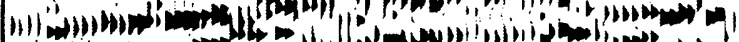
: III/

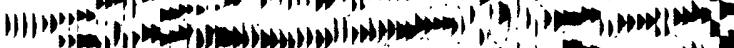
"1".

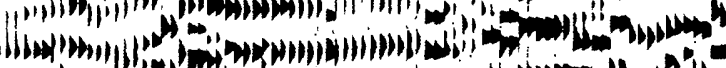

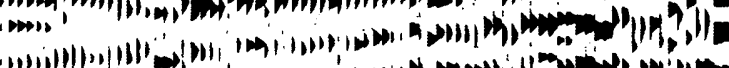
- III '

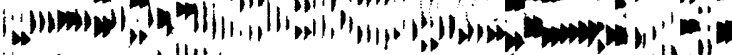

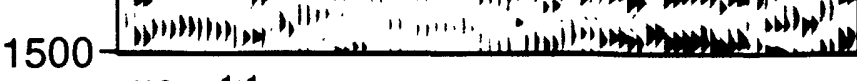
v.e. $=1: 1$

\section{Projection of Trench \\ surface crack SC}

NW

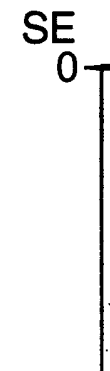

bi, lowion, H,

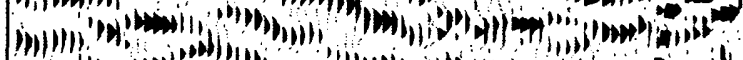
(WI)!? ?

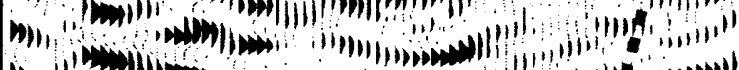

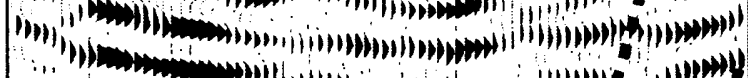

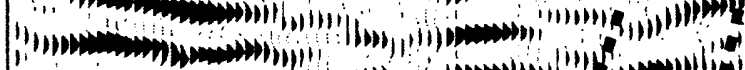

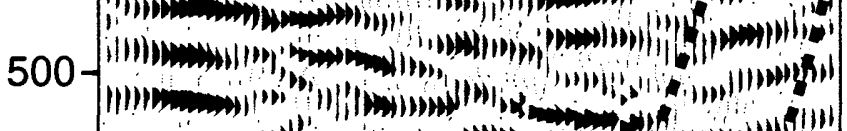

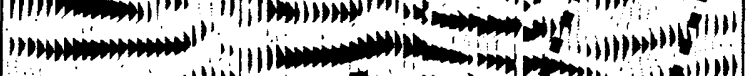

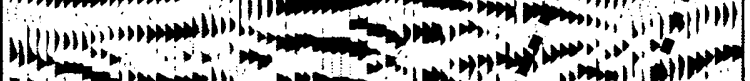

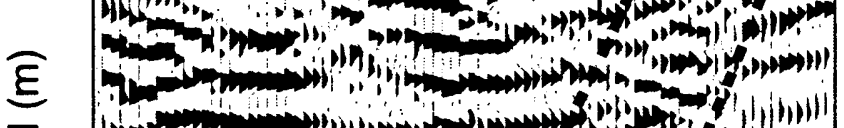

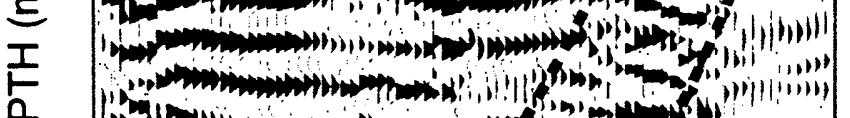

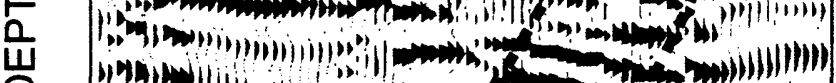

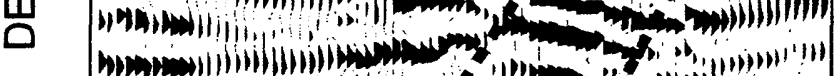



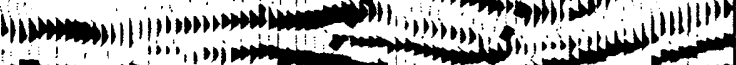

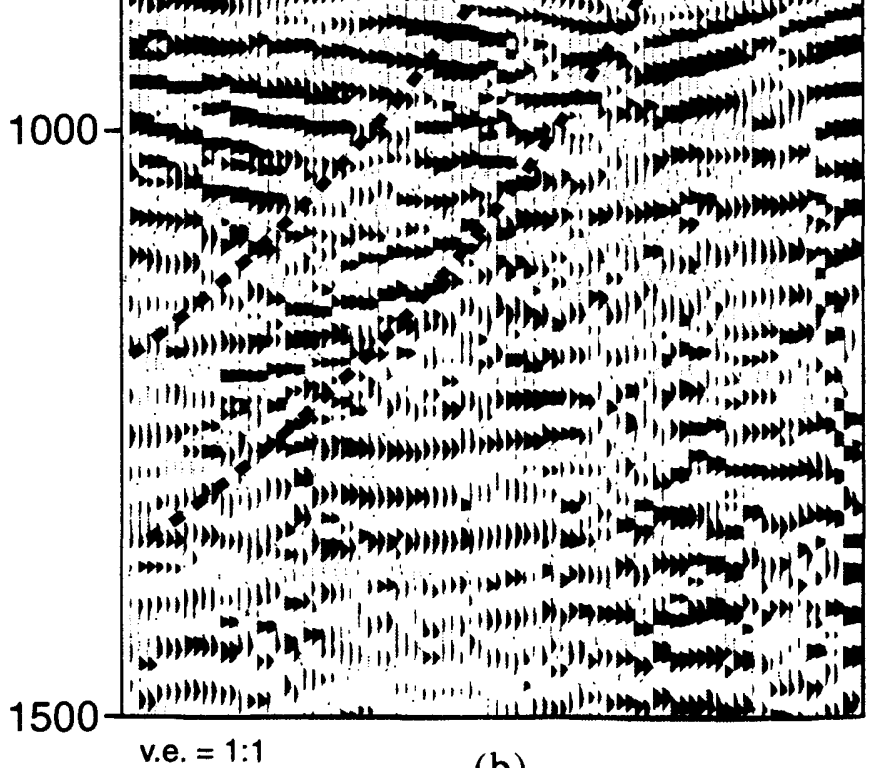

(b)

Figure 10. Uninterpreted (a) and interpreted (b) migrated seismic reflection image of shallow crust $(<1.5 \mathrm{~km})$ beneath Potrero Canyon. Locations of surface cracks and a paleoseismological trench are shown. Common depth points (CDP) are shown along the top and depth in meters is shown along the vertical axis. Depth is relative to the topographically lowest point along the surface of the profile. 


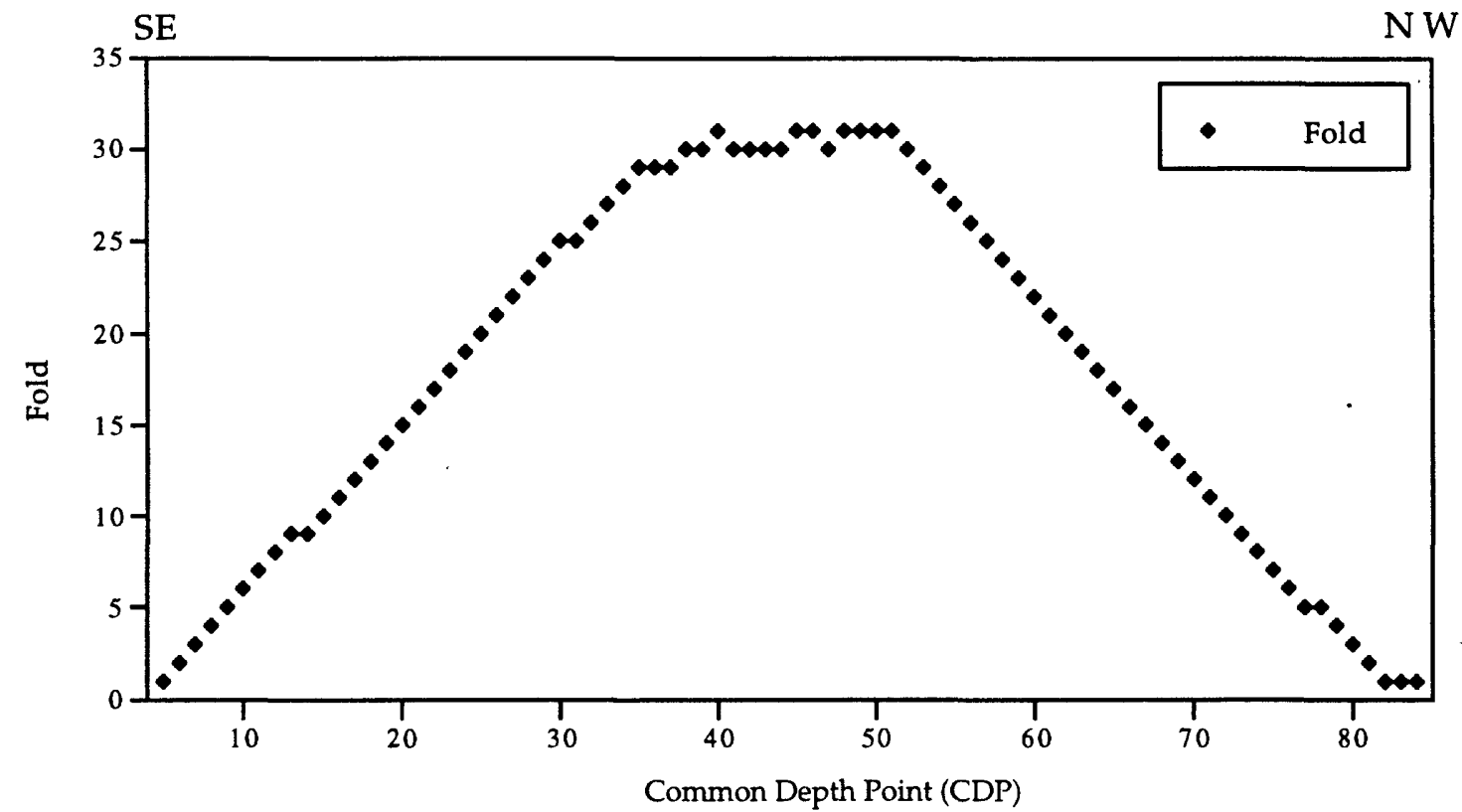

Figure 11. Fold as a function of common depths points along the seismic line. Distance is relative to the first geophone at the southeast end of the line.

\section{Potential Earthquake-Hazards}

The seismic velocity data and the seismic reflection images are suggestive of faults beneath Potrero Canyon that extend to the surface or near-surface. At depth, there appear to be at least two thrust faults that have little expression at the surface, suggesting they are blind thrusts. It is likely that the imaged thrust faults extend much farther south beneath the Santa Susana Mountains. Such thrust faults pose an obvious seismic hazard to the area; however, the extent of the thrust faulting is not known. The Santa Susana Mountains are undergoing active tectonism, and the fact that such faults are imaged beneath a rapidly developing area is a compelling reason to conduct further imaging studies to quantify the hazard in the area.

\section{DATA AVAILABILITY}

The data presented in this report are archived at the USGS (Menlo Park) in SEG-Y format. The data are available as shot gathers with elevation and shot timing corrections applied. The principal investigator (R.D. Catchings) can be contacted at the address on the cover of this report for copies of the digital data. 


\section{ACKNOWLEDGMENTS}

We thank Joe Catchings, Alexi Kolesnekov, Dave Harlow, Dan Ponti, Keith Rice, David Schwartz, Randy White, USGS NEHRP and volunteers from the USGS, Pasadena for assistance in acquiring the seismic data.

\section{REFERENCES CITED}

Catchings, R. D., M. R. Goldman, W. H. K. Lee, M. J. Rymer and D. J. Ponti (1997). Apparent thrust faults and possible co-seismic origin of surface cracks in Potrero Canyon, Los Angeles County, California, following the 1994 Northridge, California, earthquake: In press.

Hart, E.A., J.A. Treiman, and W.A. Bryant (1995). The search for fault rupture after the Northridge earthquake, in Seiple, W.R. and Woods, M., eds., Northridge, California earthquake, January 17, 1994: California Division of Mines and Geology Special Publication 116, p. 89-101.

Hecker, S., Ponti, D.J., Garvin, C.D., Hamilton, J.C., in press, Characteristics and origin of ground deformation produced in Granada Hills and Mission Hills during the January 17, 1994 Northridge earthquake, in Seiple, W.R., and Woods, M., eds., Northridge, California earthquake, January 17, 1994: California Division of Mines and Geology Special Publication 116, p. 111-131.

Hole, J. A. (1992). Nonlinear high-resolution three-dimensional seismic travel time tomography, J. Geophys. Res. 97, 6553-6562

Rymer, M. J., T. E. Fumal, D. P. Schwartz, T. J. Powers, and F. R. Cinti (1995). Distribution and recurrence of surface fractures in Potrero Canyon associated with the 1994 Northridge, California, earthquake in Woods, Mary C., and Seiple, W. Ray, eds., The Northridge, California, Earthquake of 17 January 1994: California Department of Conservation, Division of Mines and Geology Special Publication $116,133-146$

Treiman, J.A., 1995, Surface faulting near Santa Clarita, Los Angeles County, California, in Seiple, W.R., and Woods, M., eds., Northridge, California earthquake, January 17, 1994: California Division of Mines and Geology Special Publication 116, p. 103-110.

U.S. Geological Survey, and Southern California Earthquake Center, 1994, The magnitude 6.7 Northridge, California, earthquake of 17 January 1994: Science, v. 266, p. 389-397. 
Wentworth, C. M., and R. F. Yerkes (1971). Geologic setting and activity of faults in the San Fernando area, California, in The San Fernando, California, earthquake of February 9, 1971: US Geological Survey Professional Paper 733, 6-16

Winterer, E. L., and D. L. Durham (1962). Geology of southeastern Ventura basin, Los Angeles County, California: US Geological Survey Professional Paper 334, 275-366 


\section{Appendix A}

Relative locations and elevations of receivers and shot points along Potrero Canyon.

Distance is relative to the southeastern end of the line.

\begin{tabular}{|c|c|c|c|c|}
\hline Shot Number & Receiver Dist. (m) & Receiver Elev. (m) & Shot Dist. (m) & Shot Elev. (m) \\
\hline & 0.00 & 34.67 & & \\
\hline & 14.67 & 31.59 & & \\
\hline & 29.34 & 27.93 & & \\
\hline 1 & 44.25 & 26.95 & 43.99 & 26.98 \\
\hline 2 & 59.01 & 25.11 & 58.86 & 25.03 \\
\hline 3 & 74.07 & 23.91 & 73.81 & 23.91 \\
\hline 4 & 89.00 & 22.71 & 88.96 & 22.58 \\
\hline 5 & 104.00 & 21.73 & 103.99 & 21.67 \\
\hline 6 & 118.94 & 20.03 & 119.10 & 20.48 \\
\hline 7 & 134.47 & 18.98 & 134.47 & 18.98 \\
\hline 8 & 148.92 & 17.49 & 149.05 & 17.55 \\
\hline 9 & 163.85 & 16.41 & 163.33 & 16.41 \\
\hline 10 & 178.81 & 15.45 & 179.02 & 15.37 \\
\hline 11 & 193.85 & 14.40 & 194.32 & 14.32 \\
\hline 12 & 208.78 & 13.41 & 208.96 & 13.36 \\
\hline 13 & 223.92 & 12.37 & 223.93 & 12.34 \\
\hline 14 & 238.85 & 11.44 & 238.92 & 11.44 \\
\hline 15 & 253.94 & 10.42 & 254.12 & 10.44 \\
\hline 16 & 269.03 & 9.54 & 268.63 & 9.55 \\
\hline 17 & 284.00 & 8.46 & 282.87 & 8.53 \\
\hline 18 & 299.00 & 7.60 & 298.81 & 7.61 \\
\hline 19 & 314.04 & 6.84 & 314.44 & 6.85 \\
\hline 20 & 329.16 & 6.19 & 329.39 & 6.18 \\
\hline 21 & 344.36 & 5.53 & 344.43 & 5.56 \\
\hline 22 & 359.52 & 5.04 & 359.69 & 5.03 \\
\hline 23 & 374.47 & 4.52 & 374.54 & 4.49 \\
\hline 24 & 389.45 & 4.14 & 389.46 & 4.18 \\
\hline 25 & 404.48 & 3.66 & 404.77 & 3.65 \\
\hline \multirow[t]{2}{*}{26} & 419.58 & 3.23 & 419.78 & 3.25 \\
\hline & 434.59 & 2.84 & & \\
\hline 27 & 449.75 & 2.56 & 451.60 & 2.53 \\
\hline 28 & 464.89 & 2.39 & 465.14 & 2.39 \\
\hline 29 & 479.96 & 2.15 & 479.82 & 2.13 \\
\hline \multirow[t]{3}{*}{30} & 494.88 & 1.99 & 494.43 & 1.92 \\
\hline & 509.98 & 1.64 & & \\
\hline & 525.03 & 1.55 & & \\
\hline \multirow[t]{4}{*}{31} & 540.18 & 1.25 & 540.18 & 1.26 \\
\hline & 557.37 & 0.00 & & \\
\hline & 572.25 & 1.27 & & \\
\hline & 587.86 & 1.89 & & \\
\hline
\end{tabular}


Appendix A (cont.)

\begin{tabular}{|l|c|c|l|l|}
\hline Shot Number & \multicolumn{1}{c}{ Receiver Dist. $(\mathrm{m})$} & \multicolumn{1}{c|}{ Receiver Elev. $(\mathrm{m})$} & \multicolumn{1}{l|}{ Shot Dist. $(\mathrm{m})$} & \multicolumn{1}{c|}{ Shot Elev. $(\mathrm{m})$} \\
\hline & 603.96 & 5.47 & & \\
\hline & 618.80 & 9.08 & & \\
\hline & 633.97 & 11.19 & & \\
\hline & 649.52 & 13.00 & & \\
\hline & 664.74 & 15.09 & & \\
\hline & 679.75 & 18.35 & & \\
\hline & 694.38 & 21.45 & & \\
\hline
\end{tabular}

